\title{
Sports as a 'Green Product' in Destination Marketing: Case of Windsurfing in Cesme, Turkey
}

\author{
Destinasyon Pazarlamasında 'Yeşil Ürün' Olarak Spor: \\ Rüzgar Sörfü Örneği, Çeşme Türkiye
}

\author{
Gürhan Aktaş, Dokuz Eylül Üniversitesi, Türkiye, gurhan.aktas@deu.edu.tr \\ Banu Atrek, Dokuz Eylül Üniversitesi, Türkiye, banu.atrek@deu.edu.tr \\ Sumeyra D. Kurt, Dokuz Eylül Üniversitesi, Türkiye, sumeyra.kurt@deu.edu.tr
}

\begin{abstract}
Within a wide array of academic and practical studies existing in the literature on sustainable tourism development, there is still a need for further research assessing the sustainability of different tourism forms and their components. It is the argument of this research that, in the fiercely competitive tourism sector, the implementation and management of sustainable tourism development plans would offer potential benefits to sports tourism destinations alongside a 'greener' competitive advantage in marketing spheres. In this context, this research attempts to answer: whether marketing sports attractions in destinations would help stakeholders recognize the need for sustainable tourism development, and; whether sustainable sports tourism development could become a catalyst in promoting sustainable development of destinations. The specific attention is paid into tourism's impacts on natural environment, on which the sports type selected for investigation - i.e. windsurfing - highly depends for its existence. Since the analysis of a green product within a destination milieu requires thorough understanding of all stakeholders' roles within a tourism network, interviewing sector stakeholders was selected as the main research methodology for primary data collection in addition to literature review on the topics of sustainable tourism development and green marketing.
\end{abstract}

Key Words: Green marketing, sports tourism, Cesme, Turkey, windsurfing, sustainable tourism.

ÖZ: Sürdürülebilir turizm gelișimi hakkında akademik ve uygulamaya yönelik yazında yer alan çok sayıdaki çalışma, farklı turizm türleri ve ürünlerinin sürdürülebilirliğinin değerlendirilebilmesi için daha fazla sayıda çalışma yapılması gerektiğini göstermektedir. Turizm sektöründeki yoğun rekabet göz önüne alındığında, bu çalışma, sürdürülebilir turizm gelişimi planlarının uygulanmasının ve yönetiminin, pazarlama alanında spor turizmi destinasyonlarına, 'daha yeşil' olmanın getirdiği rekabet avantajının yanısıra farklı potansiyel faydalar da sağlayacağını savunmaktadır. Bu kapsamda, bu çalışma: destinasyonlarda spor aktivitelerinin pazarlanması, paydaşların, sürdürülebilir turizmin gelișimine olan ihtiyacı farketmelerine yardımcı olur $\mathrm{mu}$, ve; sürdürülebilir spor turizminin gelişmesi, destinasyonların sürdürülebilir gelişiminde bir katalizör olabilir mi sorularına cevap aramayı amaçlamaktadır. Turizmin varlığı ve geleceği, büyük oranda doğal çevreye bağlı olduğundan, turizmin doğa üzerindeki etkileri ve özellikle araştırma kapsamında incelenen ve doğa sporu ürünü olan rüzgar sörfünün doğal çevre üzerindeki etkisi üzerinde önemle durulmaktadır. Destinasyon çevresinde yer alan yeşil ürünlerin incelenmesi, turizm iletişim ağı içerisinde yer alan tüm paydaş rollerinin kapsamlı bir şekilde anlaşılması ile mümkün olabileceğinden, bu çalışmada sektör paydaşları ile yapılan mülakatlar, birincil veri toplama yöntemi olarak belirlenmiștir.

Anahtar Kelimeler: Yeşil pazarlama, spor turizmi, Çeşme, Türkiye, rüzgar sörfü, sürdürülebilir turizm.

\section{Introduction: Sustainable Tourism Development and Sports Tourism}

Tourism, if managed and developed effectively, has been proved to be a sector, which can enhance the viability and the living quality of destination settings. The economic, social and cultural benefits of the sector, such as the attraction of new investments leading to new employment opportunities for local communities and, the protection of natural and heritage resources, cannot be neglected. However, the fact that the sector relies heavily on destinations' natural, cultural and heritage attractions for survival, may also result in the overuse of these very resources, and may threaten their successful maintenance, and even existence, in the long-term. Therefore, as Liu (2003) notes, preserving, as well as promoting, the rare and unique tourist resources should be among the key strategies adopted by destination management and marketing organizations in order to nourish the competitive advantages of their destinations.

Coastal resorts, such as the case study of this research, are arguably among the most fragile destination types to the costs of ill-planned and ill-managed tourism activities and facilities. The distinctive characteristics of these resorts include: over-dependence on tourism as an economic activity; over-development along the coastline in search of maximizing the economic benefits of tourism; urbanization, and; seasonality allowing visitors to enjoy natural resources in pleasant climate conditions only during limited time periods. When Fordist forms of tourism production and consumption associated with mass and all-inclusive package holidays are added to such characteristics, diminished tourism-related benefits and unsolicited resource destruction becomes a detrimental outcome faced not only by the tourism sector, but also by the broader local communities of coastal resorts (Shaw and Coles, 2007). 
The remedy is, more often than ever, sought in sustainable tourism development. Sustainable tourism development, based on the broader concept of 'sustainable development', aims to reduce the adverse impacts and costs of the tourism sector, while optimizing its benefits shared by the sector's stakeholders ranging from host communities to visitors (Bramwell et al., 1998). The foremost challenge of the process, therefore, rests in the identification of the activities and facilities triggering such adverse effects in the natural, socio-cultural and economic environments of a tourist destination, while ensuring the longevity of irreplaceable tourist resources that would help the destination to retain its competitive advantage in the long-term.

As Welford and Ytterhus (1998) highlight, while sustainable tourism development helps destinations maintain their diversity and uniqueness in the long-term, it also requires great work and effort in the short-term and may impose additional costs to development. As the authors further add, destination management and marketing organizations, as well as local authorities responsible for the effective functioning of the sector in a destination, should be involved in a wide array of activities including: consumer education; the promotion of conservation; participation and partnership establishment, and; the management of change, if they proactively and enthusiastically employ sustainable tourism development policies and strategies. Since the process is not a static one, but demanding constant update and flexibility of strategies, there is also a need to benefit from technical knowledge of current and past practices of sustainable development plans and programs executed in the destination and learned through benchmarking studies (Byrd, 2007).

The dilemma with the implementation of sustainable tourism development, meantime, stems from the conflicting distinctions of different approaches pointing out different routes to 'sustainable' success. In contrast to 'fundamentalist' researchers supporting the minimization of travel flows to naturally, culturally, socially and historically fragile destinations for the protection of resources and community values, the 'technocentrism' approach, as Bramwell et al. (1998) discuss, argues that the instrumental value of resources to society could only be sustained through their effective planning and management. Moreover, the later approach rationalizes increased tourism development from the perspective that sustainable tourism development could only be achieved through economic growth and the betterment of the sector through scientific thinking, which would shed light into the protection of resources and the elimination of adverse impacts of the sector.

While the technocentrism approach considers the effective and protective usage of tourism and community resources not only for future generations, but also for today's communities and consumers, within the premises of sustainable tourism development, an academic attention is also paid to different tourism forms that are considered more 'sustainable' than others. Liu (2003), for example, refers to such tourism forms, among which ecotourism, alternative tourism, responsible tourism, soft tourism, low-impact tourism and community tourism are listed. In a similar way, Weaver (2006) investigates the sustainable aspects of farm-based tourism, volunteer tourism, education tourism and ecotourism. In such existing literature, however, the development of such tourism forms with narrow product-centered perspectives is also criticized for not laying the enduring grounds of sustainable tourism development (Pforr, 2001). Ecotourism, for example, which is arguably recognized by the worldwide tourism sector as the 'greenest' tourism form of all, has been referred by both Pforr (2001) and Liu (2003) more as a marketing tactic rather than a sustainable development instrument, providing both destinations and tourism establishments with competitive advantages over their rivals through the diversification of their tourism product portfolios. The authors also comment on the negative impacts experienced by so-called ecotourism destinations, where tourists encouraged to flow into once untouched natural zones in high volumes, hence threatening the existence and protection of wildlife species and habitat.

The literature on sustainable development is not limited to the examination of the above-mentioned tourism forms. Various authors have also studied the concept within the field of sports tourism - the main interest of this research. Although the motivations for taking part in sports holidays as well as the provision of sports tourism products would vary according to the type of sports under investigation, there is no doubt that the development of this particular tourism form is strongly related to the protection of natural, economic and socio-cultural resources of destinations. Among these, natural resources are of utmost importance, as they are often required for the actual practicing of many sports, as in mountaineering, water sports, skiing and paragliding. This is also the reason why many sports complexes and facilities pose threats to the sustainable development of tourist destinations. While major ski resorts can cause erosion and deforestation during the building of slopes and accommodation establishments, water sports may result in over-harvesting of marine wildlife, the pollution of water and the destruction of coastal vegetation (Glyptis, 1991). Yet, since visitors become more participative than inactive in sports holidays, one can argue that the protection of destination resources is easier to achieve in sports tourism, where the concerned stakeholders ranging from suppliers to consumers, are more likely to establish strong co-operation -an imperative prerequisite of sustainable tourism development (Welford and Ytterhus, 1998).

Among the existing literature focusing on the sustainable development of sports tourism, Videira et al. (2006) investigate the impacts of the golf courses in Portugal on three dimensions of analysis - i.e. environment, business and regional economy- and, define a sustainability assessment framework for the positioning of the regional performance of golf courses. The authors argue that the elimination of negative environmental effects of 
golf courses including the excessive consumption of water for irrigation and, of fertilizers for greener courses, can be facilitated through voluntary instruments adopted by small- and medium-sized supplier establishments. Such voluntary instruments are categorized as Environmental Management Systems and Environmental Management Programs, and are argued to generate benefits of: improving the 'green' image of the participating organizations to consumers; improving the competitiveness of golf courses, and; facilitating of corporate environmental responsibility towards sustainable development.

As opposed to the supply side focus of Videira et al.'s research, Flagstad and Hope (2001) introduce sustained value creation in winter sport destinations, which is associated with: subjective well-being of local residents; optimum satisfaction of guest requirements; unspoiled nature and protection of resources, and; healthy culture supported by economic prosperity of the destination. The authors also note that sustain value creation can be achieved through: the configuration of the destination product; the establishment of the destination organizational structure; the implementation of sustainable development policies, and; the maintenance of the destination's comparative advantage.

Another research in the field has been conducted by Buckley (2002), who investigates the sustainable development of surf tourism in Indo-Pacific Islands. Despite the fact that demographic characteristics of surf tourism demand differs remarkably from windsurf tourism demand, hence each causing dissimilar socio-cultural impacts in destination settings (Dolnicar and Fluker, 2003a; Wheaton and Tomlinson, 2001), the commonalities between these sports such as the natural environment where they are practiced and the equipment used for practicing, strengthens the argument that they lead to similar environmental impacts. Buckley argues that such impacts are more local than global in surf tourism including: increased water consumption; pollution of drinking water supplies from waste dumps and landfills, and; euthrophication of near shore reefs and other marine ecosystems from sewage discharge.

While all the above mentioned studies contribute to the concept of sustainable sports tourism development, there is still a need for further research assessing the sustainability of different sports tourism components in varying sports types. It is the argument of this research that, in the fiercely competitive tourism sector, the implementation and management of sustainable tourism development plans would offer potential benefits to sports tourism destinations alongside a 'greener' competitive advantage in marketing spheres. In this context, the research acknowledges the technocentrism approach and attempts to answer: whether marketing green sports attractions would boost stakeholders' recognition of sustainable tourism development, and; whether sustainable sports tourism development could become a catalyst in promoting sustainable development of destinations on economically broader scales rather than the execution of the concept solely in the field of tourism. Since the time and budget constraints prohibit the research from examining socio-cultural, political, environmental and economical impacts of tourism in sports destination, the attention is paid into the impacts on natural environment, on which the sports type selected for investigation - i.e. windsurfing - highly depends for its existence. Due to the fact that the technocentrism approach promotes protecting tourism resources through sustainable use, the research is built on the assumption that sports destinations could benefit from encouraging, and even enforcing, tourism suppliers to develop green products and strategies, which as a result, justify the reliability and validity of their ‘green destination' marketing activities.

\section{Green Products, Green Marketing and Tourism}

Peattie (1995, p.28) defines green marketing as "the holistic management process responsible for identifying, anticipating and satisfying customer and society needs in a profitable and sustainable way". As the definition indicates, the development of green products, which run clean, work better and save money and energy through efficiency, help execution of green marketing activities and generate successful environmental strategies for sustainable development (Shi \& Kane, 1995 and Pujari et al., 2003).

In a later study by Peattie (2001), the evolution of green marketing is identified in three phases. The author states that the emergence of green marketing in academic literature coincides with the 1970s, which is the first phase called 'ecological green marketing'. In this phase, companies and consumers concentrated on widespread ecological threats such as air pollution. The second phase, started in the late 1980s, is called 'environmental green marketing'. During this phase, serious environmental disasters, such as the 1986 Chernobyl catastrophe, were experienced and public awareness with the help of extensive media coverage of such disasters, increased towards the necessity of environment protection. The harmful effects of businesses on environment were recognized and some important concepts appeared including: sustainability; clean technology; green consumer; competitive advantage; eco-performance, and; environmental quality. The third phase of green marketing is 'sustainable green marketing' of the 1990s. This phase puts an emphasis on the understanding of long-term environment protection supported by increased social and economic welfare.

Today, green marketing is considered as a corporate philosophy rather than just a tool to satisfy customers. According to this view, green marketing should be incorporated into all of the corporate decisions of businesses. Polonsky \& Rosenberger III (2001) clarify this situation through providing information about green marketing 
applications on targeting, pricing, design, positioning, logistics, marketing waste, promotion and green alliances. As the authors further note, green marketing starts by green product design and this step not only makes a product green but also lowers the design costs associated with the product. At this stage, the possible adverse effects of product design on environment should be thoroughly tested prior to production, and such possibilities should be minimized when the product is placed in its market. Bhat (1993) states that there are two green design strategies meeting such criteria: source reduction and waste management.

In their research, Pujari et al. (2003) argue that green products should be produced with latest technologies strengthening their environmental friendliness in a way that their harmful effects on environment are minimized in all possible ways including the usage of recyclable material in their production. In a further elaborative study, Chamorro and Banegil (2006) categorize green products in three levels: basic green products; extended green products, and; total green products. In basic green products, environmental concerns are only associated with the consumption and the post consumption stages, whereas the energy and raw materials consumed and, wastes and emissions generated in the development process are also taken into account for extended green products. Finally, all internal activities and external environment connections of businesses are examined in the search of their likely ecological consequences in the development of total green products.

Following product design, businesses can implement green positioning through emphasizing the green concerns of the company for the public. However, this is a challenging issue since such a positioning strategy requires being attentive in terms of not moving away from the environmental focus. The attainment of all other green marketing strategies, including: targeting; pricing; logistics; marketing waste; promotion, and; green alliances, all resemble traditional marketing strategies with the only difference of their green concerns on every step of product life cycle and marketing mix strategies. The ten step process incorporating green marketing into marketing strategy development is, meantime, introduced by McDonald and Rylander (1993) as:

1) to develop an environmental corporate policy;

2) to build environmental leadership at the top level of the organization;

3) to hire or develop environmental advocates on the inside;

4) to educate and train all employees on environmental awareness;

5) to maintain active dialogue with outside environmental groups and government agencies; 6) to develop an assertive environmental action program;

7) to integrate all departments to facilitate flexibility in responding to environmental needs;

8) to allocate adequate resources to show commitment;

9) to execute effective advertising and publicity in order to communicate to customers, and; 10) to monitor consumer response with an active marketing research program.

The dilemma with the applicability of the above mentioned concepts and strategies into tourism, stems from the fact that they are mainly introduced through the studies concentrating on manufactured goods rather than services. Walker and Hanson (1998) discuss the differences and similarities between product and service marketing and destination marketing, and investigate Tasmania as a case study. The authors conclude that the effective employment of green strategies relies on the environmentally friendly atmosphere portrayed by the destination, its tourism sector and tourist products, and the environmental awareness of local authorities and stakeholders responsible for planning, management and marketing of tourism development.

Jamrozy (2007), another author referring to green marketing of tourist destinations, argues that such sustainable marketing efforts should go beyond a resource protection, and should focus on developing environmentally safe products. According to the author, marketing green tourism forms should be supported by the green marketing practices of tourism establishments, which should favor environmentally conscious activities such as recycling and energy savings. While a sector-wide green marketing approach would result in environmental consciousness that promotes preservation and conservation of natural resources, green products targeting green visitors can still generate economic benefits without surpassing carrying capacity thresholds.

Finally, Mycoo (2006) examines a recent sustainable tourism development incentive in the form of encouraging tourism stakeholders to actively involve in seeking green certification in the Caribbean Islands. For the awarding of certification, tourism establishments need to meet various minimum standard requirements and criteria ranging from waste reduction to energy efficiency and, from an environmentally sensitive purchasing policy to environmental and historic site protection. However, as the author further adds, unless all stakeholders wholeheartedly support such certification programs for the sustainable development and green marketing of both their establishments and destinations, green certificates, which can easily be perceived as another bureaucratic procedure enforced by local authorities, become a contentious issue.

\section{Research Methodology}


This research does not suggest that the use of tourism products as green products and portraying such products in marketing activities would be the core aspect of sustainable tourism development. As discussed in the initial sections, sustainable tourism development covers a broad and complex analysis and policy-making process. Without the thorough understanding of this process, the development and implementation of green marketing strategies will be in vain. Green products supported by green marketing strategies will result in effective and appropriate outcomes in terms of sustained destination environment from both supply and demand perspectives, only if the destination management and marketing authorities follow the consequential phases of sustainable tourism development undertaken in cooperation and with commitment of all stakeholders.

In its limited scope, this research attempts to develop green product and green marketing strategies in sports tourism through the examination of a windsurfing case study in a Turkish coastal resort, Cesme. Since the green product development could only be achieved through the understanding of the contribution of all product suppliers in a windsurf tourism network, interviewing sector stakeholders was selected as the main research methodology for primary data collection in addition to literature review on the topics of sustainable tourism development and green marketing. To this end, the authors conducted three field trips to the destination in subject, and conducted ten interviews with the key personnel from stakeholder organizations including: the leading public tourism authority; an association of tourist hotels; three windsurf schools; a beach clubs specialized in windsurfing activities; a beach club specialized in kite surfing; a beach club specialized in other recreational water sport activities such as jet skiing and water skiing; a windsurf equipment retail shop, and; a property development agency specialized in construction and zoning regulations in destination zones where windsurfing is practiced.

As the organizations represented during the data collection indicate, the research focused on the supply aspect of the windsurfing experience of Cesme. Given the time and financial restrictions of the present research, it was unfeasible to design, apply and analyze a survey of those visitors either practicing windsurfing or attending sports tournaments as spectators in the case study destination. In fact, there is a particular need for further research on the demand side of this particular tourism form to understand whether windsurfing athletes and spectators can be considered as green consumers searching for green experiences. Inevitably, the research relies on the existing literature on such demand-side characteristics of windsurf tourism, which is, at the time of writing, limited in number and scope.

Since all the interviewees were expected to provide different perspectives to the subject under study, indepth and semi-structured interviews were conducted with open-ended questions enabling interviewees to express their opinions in as much detail as possible providing they are within the main concerns of the research topic. Interviews were tape-recorded with the permission of the interviewees and were immediately transcribed into verbatim reports for qualitative analysis. The selection of interviewees initially started with the identification of leading windsurfing stakeholders by the researchers, and continued with a snowballing effect when interviewed personnel recommended other professionals working in the sector.

Interview questions were asked on: windsurfing as a tourist product; the importance of both tourism and windsurfing for the destination; the impacts of the sports on the destination environment; the marketing activities presently implemented to promote Cesme, and; recommendations to improve both the destination and the sports' environmental friendliness in the long-term. In the following sections, the findings of the primary data are harmonized with the secondary data findings, while those quotations summarizing the most commonly shared opinions and those representing contrasting views are scattered into the text.

\section{Windsurfing as a Green Product in Cesme}

Cesme is a coastal resort of Turkey and is a borough of Izmir, third biggest city of the country. Located on the Cesme peninsula with a long-stretched shoreline along the Aegean Sea, the resort has two neighboring boroughs, namely Karaburun to the north and Urla to the east, both of which are also the boroughs of Izmir. As the furthest point of the country in the west, Cesme is in $80 \mathrm{~km}$ distance to the city center of Izmir. In 2012, the population of Cesme consisting of those residing in the resort all-year round, was 34,563 people, most of which are employed in service sector establishments including restaurants, hotels and retailers (IZKA, 2013). As one of the interviewees mentioned:

“...the stable winter population quadruples, at least, in summer months with the arrival of summer-house owners and their families. They are mainly those people from Izmir temporarily immigrating to spend their summer holidays in Cesme and going back with the start of school terms in autumn" [Interview 2].

In fact, the resort benefits from various primary tourist products strengthening its appeal to holiday-maker and summer-house markets. In addition to the traditional 3S product, the diversity of Cesme's tourism offer includes hot springs - spa tourism -, ruins from past civilizations - heritage tourism -, clear and deep blue sea suitable for diving, snorkeling and fishing - activity holidays -, a recently improved port facilities and a 
recently completed marina - yacht and potential cruise tourism -, a conference and exhibition center in a 5 star hotel - MICE and event tourism - and unique Cesme houses and cuisine - cultural tourism-.

As in the evolution of many other Turkish resorts along the Mediterranean and Aegean Seas, the development of Cesme as a tourist resort was triggered with government tourism incentives provided in the 1980s, but could have never achieved the success of its more popular counterparts, such as Bodrum and Kemer, in international tourism markets. This failure, partly associated with the lack of strategic destination planning and marketing activities and partly by the long-delayed improvement of accessibility until the completion of the highway connecting the resort to Izmir in 1990, arguably, had protected Cesme from experiencing the adverse impacts of unsustainable tourism development at the same time. Today, domestic visitors and summer-house owners still outnumber international visitors in the resort, while the tourism sector has found the opportunity to learn from the negative experiences such as cultural degradation and urbanization of many other Turkish resorts in its close vicinity. As the following quotation summarizes, this result has, arguably, provided the basis for the resort's tourism vision to evolve as a 'quality' and 'brand' destination where carrying capacity limits, especially in terms of international visitor numbers, can still be kept under control:

"We do not want to be like Bodrum or Marmaris, where you cannot even breathe during peak seasons. We want to attract a limited number of visitors. We want visitors to stay longer and to spend more. We want to be the Niece of Turkey. That is why we aim to develop accommodation establishments targeting high-end of the market and do not want to polarize the visitor profile by targeting those searching for budget holidays. That is not to say that they cannot find hotels suiting their budgets. But that is not our main target market... We want to expand on our brand's consistency as a quality and trendy resort” [Interview 1]

In 2012, international visitors only accounted for $11 \%$ of the total visitor figure of 257,502, who spent at least one night in registered accommodation establishments. In the same year, the accommodation capacity of Cesme consisted of 49 establishments with 9,727 bed-capacity (IZKA, 2013). While daily-visitors also flow into the destination in high numbers from Izmir and also from a nearby Greek island, Xhios, through seaways, the Ministry of Culture and Tourism has recently identified five new tourist zones to be promoted in Cesme, for which entrepreneurs are provided with fiscal incentives to invest in the resort.

Alacati, a district of Cesme, is among the most suitable international locations for water sports with its 1.12 miles width and over 3.11 miles depth clean waters and topography. According to Alacati Reconstruction Plan Revision, the total area of beaches is $288.16 \mathrm{ft}^{2}$ and the total length of the beaches is 2.985,56 $\mathrm{ft}$. The average beach depth is 98.43 feet and the Yumru Bay where windsurfing schools are located, has a water depth of 4.92 feet, sand covered shallow water area extending for 1.640,42 feet from shore into the bay that makes learning windsurfing easier for beginners. There are steady and consistent winds blowing side-shore from North to South in summer and from South to North in winter months. The yearly average of windy days in the district is 250 with an average speed of 1,55 miles per hour. Clean and clear water with an average of $18.5 \mathrm{C}$ and the opportunity to be able to swim in seven months of a year attract the attention of windsurfers, both amateur and professional divers, sailors and kite surfers.

The Windsurf Turkey Cup is organized and held every year in Alacati. The World Windsurf Championship in 2004 just before Athens 2004 Summer Olympics with an attendance of 150 windsurfers from 38 countries and the IFCA European Slalom Championship in 2005 with 40 participants from 11 countries were also held in the district. Moreover, Pegasus Airlines PWA World Cup, organized by the Professional Windsurfers Association (PWA) and the Turkish Sailing Federation attracted with 80 participants from 25 countries in 2006; 93 participants from 35 countries in 2007, and 95 participants from 35 countries in 2008 to Cesme.

The seven windsurfing schools having 44 trainers operating in Alacati providing windsurf education and training, equipment and accessories. The research executed in these schools by Sonmez (2006) on a survey sample of 282 domestic and 75 foreign windsurfer, indicated that $46.5 \%$ of the respondents are between the age of $19-39$ and $66.4 \%$ are male. $86.6 \%$ of the foreign windsurfers have moderate to advance skill of windsurfing skills whereas, only $49.6 \%$ of the domestic participants belong to this category. When the education level of the sample is analyzed, it is seen that $82.1 \%$ of the windsurfers are highly educated. $60.8 \%$ of the sample stay a week or less in Alacati.

The center of Alacati is not yet physically or environmentally damaged. Due to the preserved structure of the area, it is declared as first, second and third degree natural site area by Izmir $1^{\text {st }}$ Cultural and Natural Assets Protection Council. Being a natural site under protection both helps and endangers sustainable tourism development. While the advantages of protected zone are clear within the framework of sustainable development, the dilemmas stem from the difficulties of encouraging investors and entrepreneurs to undertake new projects in the area. As one of the interviewees raised:

"It is difficult to build hotels around here. They have placed budget hotels in the center. But they are, first, too expensive for windsurfers to afford and, second, they are away from the schools. If you want to build an establishment meeting the lodging expectations of the windsurfer market 
nearby where they can actually practice their sport, you are opposed by the zoning regulations. It is ok to build luxurious hotels, but not budget enterprises... They also shelter the protection of the cultural and environmental heritage of the district, as renovations, refurbishments and restorations are made difficult under strict regulations” [Interview 4].

While small size investment projects are under close scrutiny of the public authorities, the Port Alacati, a 500 million euro project undertaken by the consortium called Alacati Tourism Investments, has been recently completed. The project consists of more than 3,000 construction units on a total area of 568,34 ha with different architectural styles, a port providing storage for over 500 boats, stores, sports and cultural centers, along with shops and hotels. $15 \%$ of the buildings that is planned to be constructed in this area will be 3-floor high, while the rest will be 2-floor high. Necessary permissions and approval from the Cultural and Natural Assets Protection Council are provided for the project. This project can be argued to contribute to the economic profitability of sustainable tourism development by attracting high-income level tourists to Cesme. However, the location of the project severely threatens the convenient conditions for the environmental sustainability of the windsurf tourism in the area.

Two interviewees stated such problems with the project:

"The project is very close to the windsurfing area. Even the construction phase was enough to block the wind that blows side-shore from North to South, and makes this area a superb location for windsurfing. Without such winds, we would lose this unique natural aspect and may become an ordinary windsurfing location” [Interview 6].

"Some of the property owners have yachts, jet skis and speed boats. They go on cruising in this part and put the safety of the windsurfers in dangers. They organized a world championship, during which athletes had to compete not only with their competitors, but also with jet-ski riders" [Interview 5].

In line with such quotations, another interviewee argued that there is a lack of environmental consciousness in the area:

"There is no electric and water saving. Even the lights in the highway are on during the day" [Interview 1].

Another interviewee also stated that the equipments of windsurf schools should be cleaned with water in order to get rid of the salty water spoiling the equipments. As a result, water consumption in these schools is at a significant level. Some of the environmentally concerned managers recycle the used water and use it for land and plant irrigation. On the other hand, most of the school managers are not even aware of the recycling method. Only one of the windsurfing schools disposes its sewage into a big hotels' treatment system next to the school. The others' sewage is collected by the tankers of the municipality. The wastewater system for most of the area consists of septic tanks that are emptied regularly by tankers, and at a number of locations where it has severe localized impacts where the sewage is discharged. Only the town of Alacati has piped collection systems. These systems have physical problems and discharge untreated wastewater into streams. Separate sewage systems are under construction to serve Cesme and Alacati. Main trunk sewers, two pumping stations and two 1,300m long sea outfalls have been completed. Solid wastes are disposed of at the Cesme Damp (Environmental Assessment Report, 1998).

Turkey's first wind power plant was set up in Cesme in 1998 in collaboration between Alacati Municipality and Gucbirligi Holding A.S. Alacati Wind Power Plant (ARES) consisting of 12 wind machines and 44 turbines. Its total energy production level is 7.2 MW. A new wind farm built in Alacati on the slopes of the Karakoy Hill producing a further $80 \mathrm{MW}$ of electrical energy by means of 49 turbines. It is considered to establish $500 \mathrm{MW}$ solar, $100 \mathrm{MW}$ geothermal energy production units supplying energy for the need of the region. It is thought to establish hydrogen production and storage unit, initially from the excess wind later from other methods, to be utilized in the production of electrical energy and fuel for electric cars. The batteries are charged by the fuel cells that convert hydrogen to heat, water and electricity.

Since 1992, water supply to the area has been supplied mainly from the Ildir springs with a number of small wells. However, over-pumping is affecting the Ildir source through saline intrusion. Moreover, due to the present method of sewage disposal in the area, contamination in some of the wells is observed. Also the Kutlu Aktas Dam provides a new source of water to Cesme since 1999.

\section{Recommended Strategies for Green Marketing of Cesme}


Sustainable green marketing aims to place an understanding of long-term environment protection and increase social welfare. Sustainable green marketing derives from three objectives; futurity, equity and emphasis on needs. Futurity points out the importance of taking into consideration community's needs in the future. Second important underlying component of sustainability is equity which aims to allocate benefits and costs around the nations fairly. The third component, emphasis on needs, points to the marketers' fallacy on targeting consumer wants (Peattie, 2001). Around the world there are so many countries which lack the satisfaction of basic needs; therefore on the route to sustainability, consumer needs should be satisfied.

In the light of the information gathered from the interviews, the following suggestions are drawn for the green marketing of windsurfing in Cesme in order to reach sustainable tourism development.

a) Cesme as a tourism destination presents a quality of life that is rich in environmental resources. Unfortunately, lacking tourism action plan and environment protection plan, Cesme is not able to use and maintain its environmental potential. Wind energy usage through wind mills for Alacati's partial electricity and the water recycling systems used by some of the windsurfing schools provide hope for sustainable environment protection. But at the same time significant amount of water is used to clean the equipments in the windsurf schools. It is suggested that the windsurfing schools, which are located next to each other can build a common water refinement system and use the recycled water in different ways to decrease water consumption. In terms of green marketing, the negative environmental consequences of Cesme as a product (air pollution, water pollution etc.) should be diminished starting by constructing a waste management system which includes the reduction, reuse and disposal of the waste (Bates and Philip, 1998).

b) On the reduction strategy, the wastes should be reduced at the source. Reusing of waste could be considered as another strategy. The irrigation system used in one of the windsurf schools can be given as an example for this strategy and can be widened in the area. Waste disposal should be done with the use of modern methods. The typical climate flora is lemur in the district and forested area is small. Therefore, forestation activities should be done with carefully constructed modern irrigation systems. All these suggestions will facilitate the green positioning of Cesme as a green product.

c) Green consumers are willing to pay more for environmentally friendly products in case they are persuaded that the company/destination has ecological concerns (Laroche et al., 2001). Therefore, after fulfilling the suggestions made earlier for Cesme as a green destination and windsurfing as a green product, the tourism agencies and the government authorities in Cesme should emphasize these applications through promotional activities to attract green consumers to the district, which would make a contribution to regional economic development. In terms of positioning strategies, Cesme tourism authorities can create a slogan emphasizing windsurfing as a green product and highlighting the current logo of Cesme which shows a sail and sun on Cesme castle. The road signboards on the streets of Cesme showing hotels are, also, designed in a shape of sail which can be used in advertisements and brochures of Cesme for green positioning (see Figure 1 and 2). Also windsurf magazines should be intensively used as a promotion tool in international target markets.

d) Cesme does not have a unique promotion strategy. Several tourism unions promote Cesme via trade fairs, seminars and advertisements. Therefore, government authorities, tourism unions and travel agencies should form integrity to develop a tourism plan and a promotion strategy for the product package of Cesme. Within this promotion strategy, customer segmentation model of Cesme should be constructed and the green customer segment should be targeted through green promotion activities such as sales development, personal sales, advertisement, direct marketing and public relations. According to Wong et.al.(1996), for green promotion activities green public relations are thought to be the most effective promotion tool. Consequently, in Cesme a green public relations department should be established and the green image of Cesme should be promoted. The promotion activity in question will enable the development of consumers' environmental awareness. The interviewees stated that windsurf and other water sports, which are available in Alacati, are totally environmentally friendly sports with no positive or negative impact on environment. Windsurfing, kite surfing, diving and sailing can all be promoted as a tool to attract green consumers who are interested in water sports to Alacati-Cesme. Also, the national and international windsurfing and other sports activities should be broadly mentioned both in domestic and foreign media. 


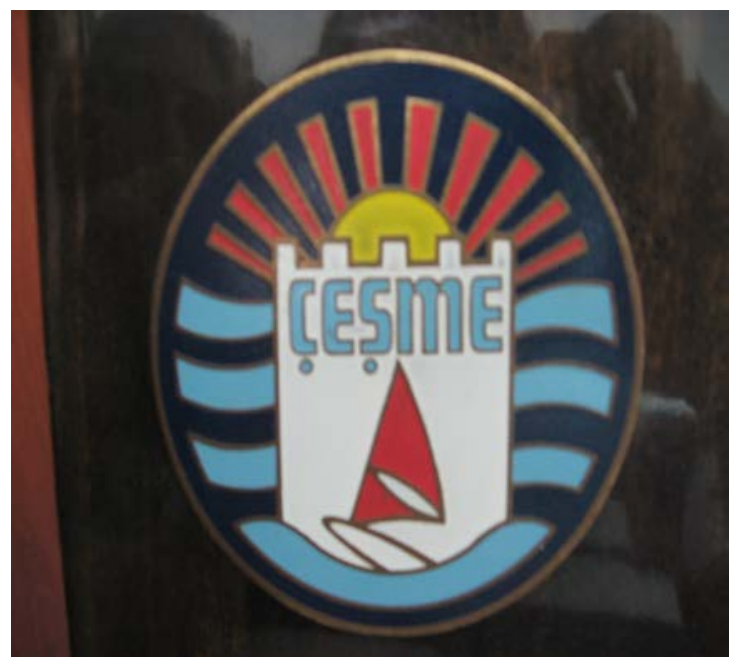

Figure 1. The present logo of Cesme using windsurfing as the core concept

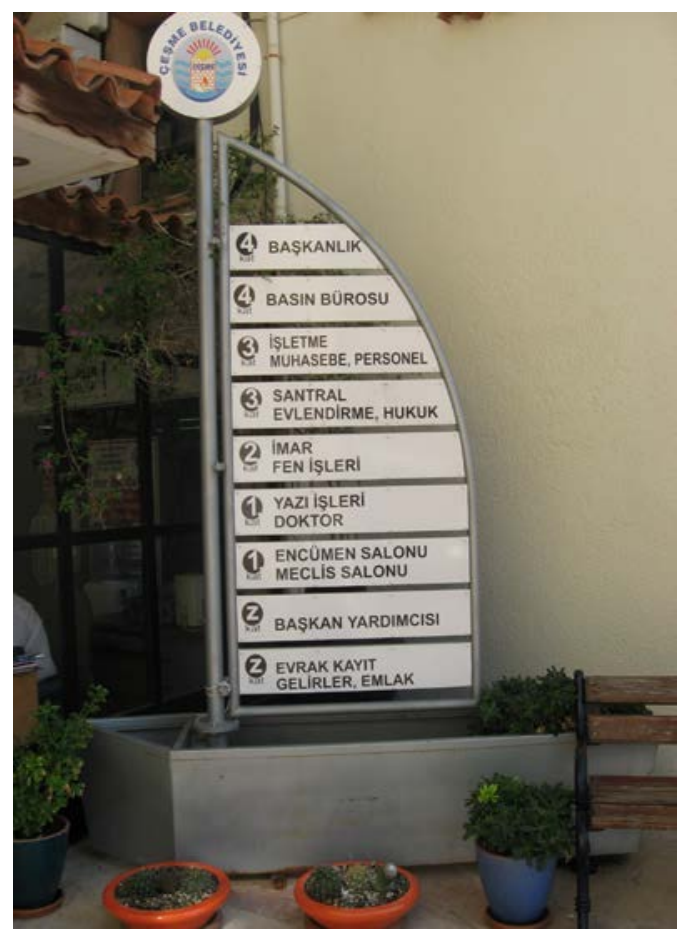

Figure 2. Windsurf shaped signboard on roads

e) From the information provided by the interviewees, it can be concluded that the consumers preferring Cesme as a tourist destination and the residents do not seem to have developed an environmental concern. There is an urgent need to protect the ecological environment which involves: the elimination of tourism caused negative environmental impacts; the education of locals on the sustainable tourism development and its benefits for the tourism sector; the use of environmentally friendly products and processes especially in new product development (Prakash, 2002). That is why in Cesme, consumer awareness of the ecological protection, should be intensified through education programs and seminars.

\section{Conclusion}


Since tourism is a fragmented sector with numerous stakeholders operating interdependently in destination setting, marketing them as green environments with quality green products is a difficult task to achieve. Nevertheless, it is also the sector, for which the protection of natural resources is crucial for the safeguarding of this very primary product that various attractions depend on for their success and existence. Besides, various environmentally friendly management and policy concepts, such as sustainable development, ecotourism and nature-based tourism, have long been studied and practiced in tourism academic and professional circles, which can be argued to have prepared the sector to move towards green marketing applications on a destination scale. As Welford and Ytterhus (1998) noted a decade ago, the implementation of effective policies and plans, tourist destination can be marketed as sustainable product clusters, while tourism establishments operating in such green environments not only benefit from this labeling of the area, but also strengthening its competitive edge through adopting similar green strategies throughout the development, management and marketing of their individual products and services.

The present study is focused primarily on a multidisciplinary approach for Cesme's sustainable tourism development. Even though Cesme has a great importance in Turkey's tourism sector, there is a lack of tourism planning for sustainability. The potentials owned by the district are disregarded for short-term profit maximization. Since tourism sustainability is the main goal in order to preserve economic, social and environmental welfare, in this study only the environmental dimension is focused and green marketing is offered as a tool for environmental sustainability.

Green marketing requires the companies to carry environmental concerns for their marketing decisions in order to address consumer and society needs in a profitable and sustainable way. This approach enables the companies to increase their profits through green consumers who are willing to pay more for environmentally friendly products. This philosophy can be applied for tourist destinations that are attentive for environmental protection. Since Cesme has a water sports potential, which are totally environmentally friendly, green marketing and windsurfing as a green product can be an alternative for attracting more tourists.

\section{References}

Bates, M.P. and Phillip, P.S. (1998). Waste Minimization in the Food and Drink Industry. Nutrition and Food Science, Vol.6, pp.330-334.

Bramwell, B., Henry, I., Jackson, G. and Van Der Straaten, J. (1998). A Framework for Understanding Sustainable Tourism Management, In "Sustainable Tourism Management: Principles and Practice", ed. by B. Bramwell, I. Henry, G. Jackson, A.G. Prat, G. Richards and J. Van Der Straaten, Tilburg: ATLAS and Tilburg University Press, pp.23-71.

Buckley, R. (2002). Surf Tourism and Sustainable Development in Indo-Pacific Islands; I. The Industry and the Islands, Journal of Sustainable Tourism, Vol.10(5), pp.405-424.

Burak, S., Dogan, E. and Gazioglu, C. (2004). Impact of Urbanization and Tourism on Coastal Environment, Ocean and Coastal Management, Vol.47, pp.515-527.

Byrd, E.T. (2007). Stakeholders in Sustainable Tourism Development and Their Roles: Applying Stakeholder Theory to Sustainable Tourism Development, Tourism Review, Vol.62(2), pp.6-13.

CTD (Tourism Directorate of Cesme). (2008). Tourism Statistics of Cesme, Unpublished Official Report, Cesme, Izmir.

Dolnicar, S. and Fluker, M. (2003a). Behavioral Market Segments Among Surf Tourists: Investigating Past Destination Choice, Journal of Sport Tourism, Vol.8(3), pp.186-196.

Dolnicar, S. and Fluker, M. (2003b). Who's Riding the Wave? An Investigation Into Demographic and Psychographic Characteristics of Surf Tourists, CD Proceedings of the $13^{\text {th }}$ International Conference for the Council of Australian University Tourism and Hospitality Education, Coffs Harbour, 5-8 February 2003.

Environmental Assessment Report. (1998). Southwest Coast Environmental Project Feasibility Study for CesmeAlacati and Surrounding Area, www-wds.worldbank.org, accessed on 28.09.2008.

Flagestad, A. and Hope, C.A. (2001). Strategic Success in Winter Sports Destinations: A Sustainable Value Creation Perspective, Tourism Management, Vol.22, pp.445-461.

Glyptis, S.A. (1991). Sport and Tourism, Progress in Tourism, Recreation and Hospitality Management, Vol.3, pp.165-183.

IZKA (Izmir Development Agency). (2013). 2014-2023 Izmir Bolge Planı: Cesme Ilce Plani, Izmir: IZKA Publication.

Jamrozy, U. (2007). Marketing of Tourism: A Paradigm Shift Toward Sustainability, International Journal of Culture, Tourism and Hospitality Research, Vol.1(2), pp.117-130.

Laroche, M., Bergeron, J. and Barbaro-Forleo, G. (2001), Targeting Consumers Who Are Willing to Pay More For Environmentally Friendly Products, Journal of Consumer Marketing, Vol.18(6), pp.503-520.

Liu, Z. (2003). Sustainable Tourism Development, Journal of Sustainable Tourism, Vol.11(6), 459-474. 
Mycoo, M. (2006). Sustainable Tourism Using Regulations, Market Mechanisms and Green Certification: A Case Study of Barbados, Journal of Sustainable Tourism, Vol.14(5), pp.439-511.

Peattie, K. (1995). Environmental Marketing Management. Pitman: London.

Peattie, K. (2001). Towards Sustainability: The Third Age of Green Marketing. The Marketing Review, Vol.2, pp.129-146.

Pforr, C. (2001). Concepts of Sustainable Development, Sustainable Tourism and Ecotourism: Definitions, Principles and Linkages, Scandinavian Journal of Hospitality and Tourism, Vol.1(1), pp.68-71.

Prakash, A. (2002). Green Marketing, Public Policy and Managerial Strategies, Business Strategy and The Environment, Vol.11, pp.285-297.

Shaw, G. and Coles, T. (2007). The Resort Economy: Changing Structures and Management Issues in British Resorts, In "Managing Coastal Tourism Resorts: A Global Perspective”, ed. by S. Agarwal and G. Shaw, Clevedon: Channel View Publications, pp.40-55.

Videira, N., Correia, A., Alves, I., Ramires, C., Subtil, R. and Martins, V. (2006). Environmental and Economic Tools to Support Sustainable Golf Tourism: The Algarve Experience, Portugal, Tourism and Hospitality Research, Vol.6(3), pp.204-217.

Weaver, D. (2006). Sustainable Tourism: Theory and Practice, Oxford: Elsevier Butterworth-Heinemann.

Welford, R. and Ytterhus, B. (1998). Conditions for the Transformation of Eco-tourism into Sustainable Tourism, European Environment, Vol.8, pp.193-201.

Wong, V., Turmer, W. and Stoneman, P. (1996). Marketing Strategies and Market Prospects For Environmentally-Friendly Consumer Products, British Journal of Management, Vol.7, pp.263-281. 